summit are conspicuous. These are apparently as yet unidentified and unmeasured. They rise at no great distance beyond Chomokankar, and are probably south of the Tingri Maidan."

During late years much has been written about the effect of rarefied air at high altitudes on the human system. Mr. Freshfield and his party suffered but little inconvenience, even when on the summit of the Jonsong $\mathrm{La}(20,207$ feet). That the effects of low barometric pressure have been much exaggerated is also borne out by the experience of Mr. White, political officer in Sikkim, who says:- "I find that the height is felt most at from 14,000 to 16, ooo feet, and that if they (the coolies) once get over that, going to a still higher altitude has very little further effect. Personally the height does not affect me, and I felt perfectly well at 21,200 feet."

The geology of the district is most ably described by Prof. Garwood, by whom also an excellent map of the whole Kanchenjunga range has been made.

Mrs. Le Mesurier has contributed a chapter on Tibetan curios, and in the appendix, besides the exhaustive description by Prof. Garwood of the geological structure and physical features of Sikkim, there is a mass of important and interesting matter collected by the author; on the narratives of journeys made by native surveyors; on the various native names for the highest measured peak (Mount Everest); also a most useful list of books and maps consulted, and last, but not least, a list of photographs taken by Signor V. Sella during the tour of Kanchenjunga.

" Round Kanchenjunga" is a book worth reading from many points of view; it is not merely a tale of mountaineering adventure, but is full of information, artistic description, and new facts. It is a book which undoubtedly will be "serviceable to Alpine climbers and men of science, and not without interest for those who 'love the glories of the world' and count among them great mountains."

\section{HIGHER EDUCATION IN THE UNITED STATES.1}

$A$ LL intelligent attempts to make known in this country the extent and success of American educational enterprise deserve encouragement. well considered an effort as that of Mr. Mosely not only merited but has received enthusiastic appreciation. By securing the assistance of educationists representative of successive steps in a complete educational system, Mr. Mosely has been able to bring together in convenient compass authoritative expressions of opinion as to the precise state of each grade of education in the United States, and to provide our new educational authorities with information as to the characteristics of American education which good judges think might with advantage be copied in this country. Similarly, the features of the work of schools and colleges in the States which should be discouraged among us are in this report duly indicated. Mr. Mosely has, too, made arrangements to ensure a wide circulation for the valuable material collected under his auspices. By forwarding to the publishers of the volume the cost of postage and stating his qualifications, any member of an educational authority, any county councillor, local manager, headmaster, or registered teacher may obtain a copy of the book free.

The twenty-six separate reports contained in the volume cover the whole field of education from the kindergarten to post-graduate university study, but it 1 " Reports of the Mosely Educational Commission to the United States of America, October-December, rgo3." Pp. xxiv + 400. (London: Co operative Printing Society, Ltd., Ig04.) Price Is., post free Is. $4 d$.

No. I8OI, voL. 70] will be possible in this place to refer to a few only of the more important directions in which American practice offers British educationists food for serious reflection. The most prominent place may well be given to an impression received by all the commissioners alike, and recorded first in their joint report; we refer to "the absolute belief in the value of educam tion both to the community at large and to agriculture, commerce, manufactures, and the service of the State " which distinguishes the inhabitants of all the United States. Side by side with this record of their observations must be placed the commissioners' message to their countrymen, which is expressed as a desire "to impress on the British public the absolute need of immediate preparation on our part to meet such competition" as this enthusiasm for education in America will lead us to experience. Evidence of the advances in American education, and also of the sacrifices made in the States to endow and develop colleges and universities, have been frequently laid before readers of NATURE. But though here and there in Great Britain a desire has been manifested to found new universities, and though we are glad to admit that a few of our men of wealth have emulated the examp'e common among American millionaires of giving largely to educational institutions, a general awakening on the part of the nation so far as a thorough belief in education is concerned is still a matter of the future. Meanwhile, the schools and colleges of the United States go steadily on with their work of preparing the rising generation. As Mr. W. P. Groser, who was nominated to the commission by the Parliamentary Industry Committee, says in his report, "England is now competing with American commerce in the making. In the next generation our manufacturers will meet trained men, adding culture to their enterprise and knowledge to their ambition."

Another striking difference between the English and American attitude towards education is appreciated by comparing the relations in the two countries bebetween industry and higher scientific and technical instruction. The report makes it abundantly clear that in America there is complete sympathy between the manufacturers and the college professors, and that properly trained college men are in great demand. Says Prof. Ayrton, "I saw that there actually existed that close bond of union between the industry and the teaching which only the more sanguine of us have hoped they might, perhaps, live to see introduced into our own country." Mr. Blair asserts, "the relationship between the schools and the industries has become one of supply and demand." Prof. Ripper states, "We were frequently told that "the American manufacturer twenty years ago, like the English of to-day, thought little of the technically trained men. The difference between us now is that the American has changed his opinion, while England appears to be where she was "" Commissioner after commissioner gives instances of the large proportion of men educated at college who are engaged in great manufacturing concerns in the States. Out of 10,000 employees in the Westinghouse shops and offices, there are 160 college-trained men employed. At the Carnegie Steel Works, where there are 7000 hands, about a hundred technically trained men are engaged, seven of the twenty-three leading officers being college graduates, and similar cases might be multiplied indefinitely.

The same enlightened policy is adopted in the matter of apprentices. Prof. Ayrton was told everywhere, " an engineering apprentice in a factory should be a college trained man," and the foreman of the apprentices at the Westinghouse works informed him, "the engineering apprentices, of whom we have about ${ }^{5} 5^{\circ}$, 
must be first-class graduates of leading technical schools. We start them on trial at $8 d$. an hour, and if really bright they may be earning $30 l$. a month with us at the end of eight months. We are always on the look-out for bright men; we cooperate with the professors of colleges to get them." "Two of the chiefs of the staff of the Westinghouse Company," says Prof. Ayrton later, "visit all the principal universities, colleges, and technical schools throughout the United States every year for the purpose of seeing the students, and choosing those who are most suitable to work with the Westinghouse Company." College students, too, are encouraged to work in the shops during vacation time, and in this way to supplement theoretical knowledge with practical experience.

Still another way in which the connection between the training given in the technical schools and colleges and the needs of industry is in America made intimate and real is to be found in the conditions of tenure pertaining to professorships. All the practical men engaged in engineering consulted by Prof. Ayrton were unanimous in telling him that "an engineering pro essor in a college should be actively engaged in the practice of his profession." Or, as he says later in his report, "engineering education in America is directed by those who are doing the engineering work of their country." Prof. Maclean's evidence is in the same direction; he states, "superior men are induced to accept collegiate appointments because of the wellequipped laboratories at their disposal, and because as engineering professors they are given every opportunity and encouragement to do outside work. It is believed that thus they keep in touch. with the various lines of progress in their profession." Prof. Ripper, too, adds his testimony to the same effect. He writes, "it is considered vital that the professor should be in the field of practice, otherwise he is liable to become stale and out of date, and to attach exaggerated importance to unnecessary things."

The scepticism of the British manufacturer as to the value of a scientific training in the workshop and factory, his neglect of the technical expert, and his ingrained conservatism are already painfully familiar to men of science. It is unnecessary to insist, in view of what this latest report tells of American enlightenment, that in the absence of an earnest endeavour by British directors of industry to follow the lead of their contemporaries in the States, the results will be disastrous-indeed, fatal-to our commercial supremacy.

To turn now to the extent that science is in America utilised in the service of the State-a matter the importance of which has been urged consistently in these pages. A joint report, signed by the commissioners as a body, places it on record that "the closest connection is being established between theory and practice, the practical bent of the men of letters and science and the breadth of their outlook being very remarkable. The services of experts in various branches of knowledge are, therefore, held in high esteem and are in constant demand." And Prof. Armstrong, in a report brimful of good things, gives numerous examples of the appreciation by the American Government of the services of men of science. To quote one or two of his obiter dicta:-_"So far as I am aware, there is nothing anywhere to compare with the way in which science is being utilised in the service of the State by the U.S. "Department of Agriculture." "There is no question that the research work done under the auspices of the Agricultural Department and in the experiment stations is of the very greatest value, and is contributing most materially to the development of agricultuial industry." "One branch of work initiated in the Office of Experiment Stations at Washington of extreme importance, to which reference No. $180 \mathrm{I}$, VOI. 70 ] should also he made, is that relating to the nutrition of man, which has been carried out in various parts of the States under the supervision of my friend Prof. Atwater." If it were necessary, similar examples from these reports could be multiplied a hundredfold.

In a short review it is possible only to touch the fringe of so great a subject. Much of value in the reports has been left completely on one side. But it is greatly to be desired that every man of science, every person engaged in education, whether as administrator or teacher, will study the volume. It is an important and absorbingly interesting contribution to a subject that deserves the immediate attention of every one of our statesmen.

A. T. S.

\section{NOTES}

THE annual conversazione of the Royal Society will be held on Friday, May 13 .

We regret to see the announcement of the death of Prof. E. Duclaux, director of the Pasteur Institute, at sixty-three years of age.

Prof. A. W. Williamson, F.R.S., is lying dangerously ill at his residence at Haslemere.

Invitations have been issued by the Royal Society of Edinburgh to a conversazione to be held in the rooms of the society on Saturday, May 28.

Prof. Henri Becquerel, of Paris, has been elected a corresponding member of the Berlin Academy of Sciences.

THE deaths are announced of Prof. Leidie (chemistry), of Paris, and Prof. Charles Soret (experimental physics), of Geneva.

IN the Physikalische Zeitschrift for April I5, Prof. Th. Indrikson states that he has repeated Sir William Ramsay's experiments showing the spectrum of helium in the emanations from radium, the experiments being in this case conducted in the physical institute at St. Petersburg, where no experiments with helium had previously been made.

Ir is announced that an annual subsidy of $35,000 \mathrm{kr}$. ( 1950 l.) for twenty years has been granted by the Icelandic Government for the establishment of a wireless telegraphic connection between Iceland and the Shetland Islands or the mainland of the United Kingdom, and also between the four principal towns of Iceland.

THE council of the Institution of Civil Engineers has made the following awards for papers read and discussed before the institution during the past session:-A Telford gold medal to Major Sir Robert Hanbury Brown, K.C.M.G., a George Stephenson gold medal to Mr. G. H. Stephens, C.M.G., and a Watt gold medal to Mr. Alphonse Steiger. Telford premiums to Mr. E. W. de Rusett, Dr. Hugh Robert Mill, Mr. Alexander Millar, and Dr. T. E. Stanton. A Manby premium to Prof. J. Campbell Brown, and a Crampton prize to Mr. L. H. Savile. The presentation of these awards, together with those for papers which have not been subject to discussion and will be announced later, will take place at the inaugural meeting of next session.

The Geologists' Association has arranged an excursion to Derbyshire for Whitsuntide. Four days are to be devoted to out-door geology. The party leaves St. Pancras for Buxton on Friday, May 20, and is expected to arrive in London from Derby on Wednesday, May 25. On Saturday, May 2I, the excursion will be directed by Messrs. H. A. 